\title{
Biological Membrane Structure By Solid-State NMR
}

\section{Michèle Auger*}

Département de Chimie, Centre Rech. Sci. Ingénierie Macromol., Université Laval, Québec, G1K 7P4, Canada

\begin{abstract}
Nuclear magnetic resonance (NMR) spectroscopy, and particularly solid-state NMR spectroscopy, is a method of choice to study the structure and dynamics of both the lipid and the protein components of model and biological membranes. Different approaches have been developed to study these systems in which the restricted molecular motions result in broad NMR spectra. This contribution will first present an overview of the different techniques used to study lipid bilayers, namely ${ }^{31} \mathrm{P},{ }^{2} \mathrm{H}$ and ${ }^{13} \mathrm{C}$ solid-state NMR spectroscopy. On the other hand, the study of the structure of membrane peptides and proteins is a rapidly growing field and several methods developed in the last two decades will be presented. These methods allow the investigation of protein systems for which structural information is often difficult to obtain by techniques such as X-ray diffraction and multidimensional solution NMR.
\end{abstract}

\section{Introduction}

During the last two decades, nuclear magnetic resonance (NMR) spectroscopy has become a method of choice for the study of the structure and dynamics of natural and synthetic macromolecules. In particular, the introduction of multidimensional NMR techniques has brought a versatile approach to the resolution and assignment of resonances in complex NMR spectra, such as those obtained in proteins $(1,2)$. These methods have been used successfully to study small molecules (molecular weight $<\sim 30,000)$ in solution. However for large proteins, polymers and membrane assemblies, spectral line broadening is encountered due to reduced tumbling rates and correspondingly longer rotational correlation times. In such cases, a good alternative is the solid-state NMR technique, which is particularly useful for the study of biological and model membranes $(3,4)$.

The solid-state NMR methods for determining the structure of biological membranes have developed along three directions. The first involves the study of powder spectra. In particular, deuterium, phosphorus and carbon NMR methods have been widely used for the study of the structure and dynamics of biological membranes. The predominant source of line broadening for deuterium is the electric quadrupolar interaction while for phosphorus and carbon, the anisotropic chemical shift and the heteronuclear dipolar coupling with protons are both strong. The second class of techniques involves the restoration of high-resolution spectra using the magic angle spinning technique $(5,6)$, which replaces molecular motions as the line-narrowing mechanism. In the magic angle spinning technique, the sample is spun in a rotor at a spinning speed typically between 1 and $15 \mathrm{kHz}$. This results in a NMR line-narrowing effect for large molecules or molecular assemblies similar to the effect of isotopic tumbling in solution. The orientational dependence of the magnetic interactions (chemical shift anisotropy and dipolar coupling), which varies with $\left(3 \cos ^{2} \theta-1\right) / 2$, averages to zero at the magic angle, $\theta=54.7^{\circ}$.

Finally, another class of techniques to obtain highresolution spectra of membrane systems consists in using either mechanically or magnetically oriented bilayer samples in order to remove the orientation dependence of the different magnetic interactions discussed above. Mechanically oriented systems are usually obtained by layering the lipid/protein mixture on thin glass plates and by hydrating these systems through the vapor phase (7, 8 ). On the other hand, specific phospholipid mixtures named bicelles are known to orient in the magnetic field, with their director oriented perpendicular to the magnetic field $(9,10)$. These bicelles are discoidal micelles formed when a long chain lipid (such as dimyristoylphosphatidylcholine (DMPC)) is mixed either with a short chain lipid (such as dihexanoylphosphatidylcholine (DHPC)) or a detergent $(9,10)$. In addition, it was recently observed that the addition of small amounts of paramagnetic ions to pure bicelles results in systems in which the director is oriented parallel to the magnetic field (10).

This paper will present an overview of the use of NMR spectroscopy, and particularly solid-state NMR spectroscopy, to investigate membrane structure and dynamics. The first section of the paper will be devoted to the study of lipid bilayers by solid-state ${ }^{31} \mathrm{P},{ }^{2} \mathrm{H}$ and ${ }^{13} \mathrm{C}$ NMR while the second part will present an overview of several techniques to investigate the structure of membrane peptides and proteins.

\section{NMR of Lipid Bilayers}

\section{Phosphorus NMR of Lipid Head Groups}

Solid-state ${ }^{31} \mathrm{P}$ NMR spectroscopy is a valuable technique to study the structure and dynamics of both model and biological membranes (11-13) since phospholipids, the major components of mammalian cell membranes, contain only one phosphate group. In addition, the natural abundance of the ${ }^{31} \mathrm{P}$ nucleus is $100 \%$.

The ${ }^{31} \mathrm{P}$ NMR lineshapes are very characteristic of the different lipid phases such as the gel and liquid-crystalline lamellar phases, the inverted hexagonal phase and isotropic phases such as small vesicles and micelles (12). An example of the use of solid-state ${ }^{31} \mathrm{P}$ NMR to investigate the interaction between proteins and lipid bilayers is shown in Figure 1, which presents the ${ }^{31} \mathrm{P}$ NMR spectra of a negatively charged phospholipid, dimyristoylphosphatidic acid (DMPA), in the absence and in the presence of the 

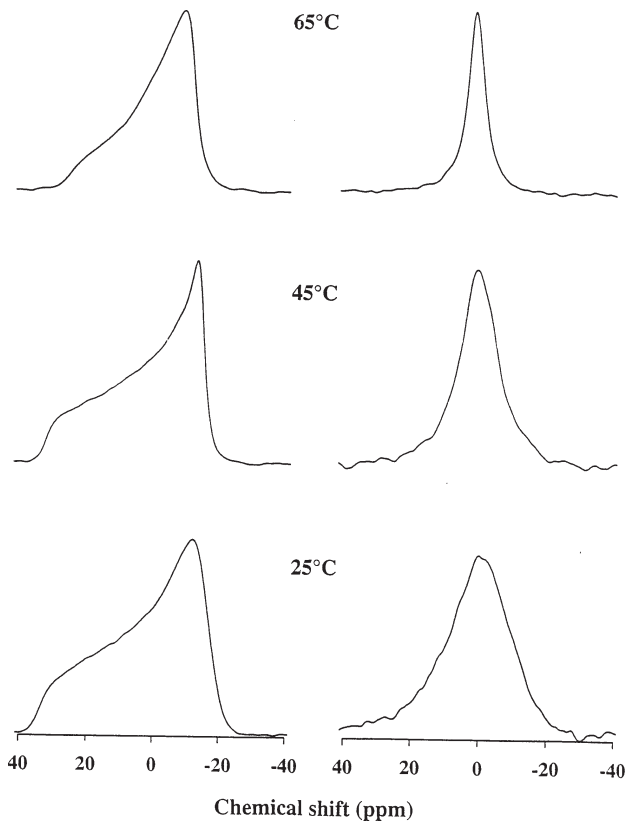

Figure 1. Temperature dependence of the ${ }^{31} \mathrm{P}$ NMR spectra of pure DMPA (left) and the complex DMPA:cardiotoxin at a lipid-to-protein molar ratio of $5: 1$ (right), (reproduced from reference 14, with permission).

protein cardiotoxin Ila extracted from the venom of the snake Naja mossambica mossambica (14).

In the temperature range between 25 and $65^{\circ} \mathrm{C}$, all the pure DMPA spectra are axially symmetric and characteristic of lamellar phases. The spectral width decreases gradually with increasing temperature with a major change between 40 and $50^{\circ} \mathrm{C}$, which corresponds to the gel to liquid-crystalline phase transition temperature of DMPA $\left(48\right.$ to $\left.50^{\circ} \mathrm{C}\right)$. The smaller spectral width obtained in the liquid-crystalline phase can be explained by an additional wobbling motion of the polar head group. The addition of cardiotoxin to DMPA at a lipid-to-protein molar ratio of $5: 1$ causes the complete disappearance of the lamellar phase spectrum and only a broad isotropic peak is present (14). This suggests that at that lipid-to-protein molar ratio, all the phospholipids interact with cardiotoxin to form an isotropic phase in which the motions are sufficiently fast to completely average the chemical shift anisotropy.

Another example of the use of ${ }^{31} \mathrm{P}$ solid-state NMR spectroscopy is the study of the lateral diffusion of lipids by two-dimensional NMR $(15,16)$. This technique uses the fact that in solid-state NMR, the chemical shielding tensor shows an orientational dependence in the static magnetic field. Therefore, it is possible to observe correlation peaks in a two-dimensional spectrum map representing an orientational exchange originating from the diffusion of lipids over the curved membrane surface. Figure 2 shows an example of such two-dimensional ${ }^{31} \mathrm{P}$ solidstate NMR spectra, obtained with the NOESY pulse sequence as a function of the mixing time $t_{m}$, for multilamellar dispersions of dipalmitoylphosphatidylcholine (DPPC) (16). These results indicate increasing off-diagonal intensity as the mixing time increases. In addition, the
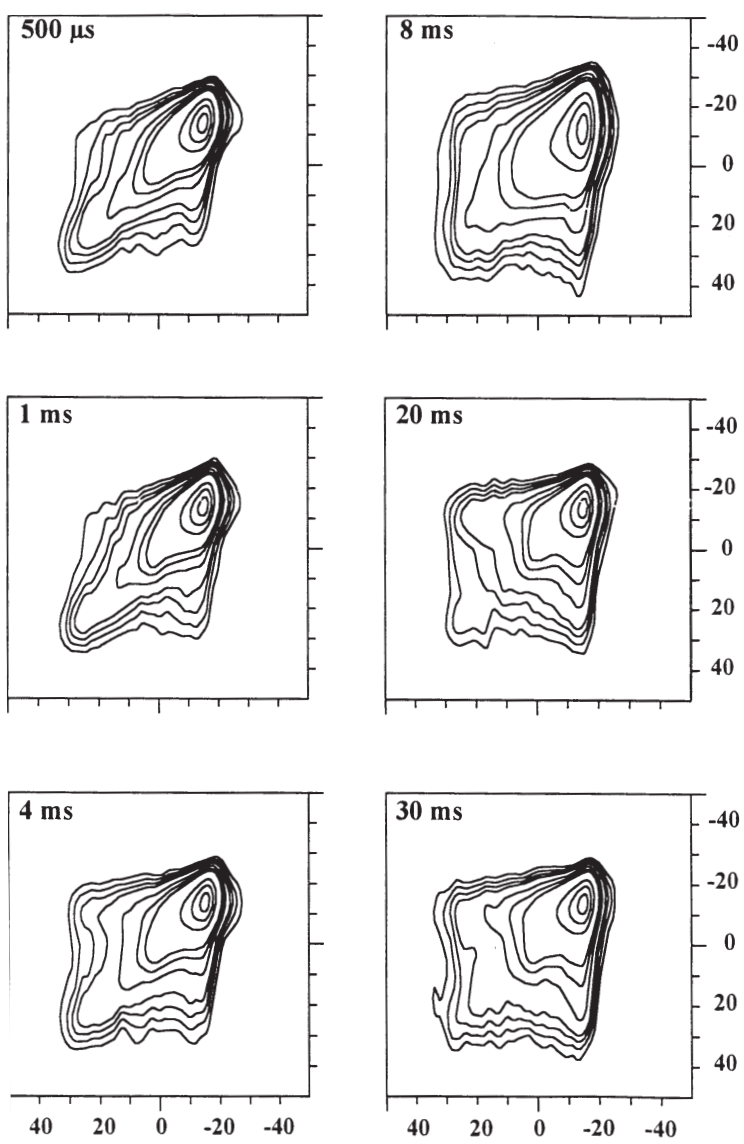

Chemical shift (ppm)
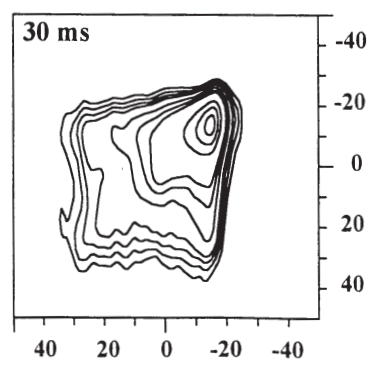

Figure 2. 2D ${ }^{31} \mathrm{P}$ NMR experimental spectra of pure dipalmitoylphosphatidylcholine (DPPC) multilamellar vesicles at $50^{\circ} \mathrm{C}$ for different mixing times $t_{m}$ (reproduced from reference 16, with permission).

diffusion constant determined from these spectra, namely a diffusion constant of $8.8 \times 10^{-8} \mathrm{~cm}^{2} / \mathrm{s}$, is in agreement with the ones determined by other techniques (16).

\section{Deuterium NMR of Lipid Bilayers}

Deuterium NMR spectroscopy is a valuable technique to study the structure and dynamics of lipid membranes in the liquid-crystalline phase (17-19). As mentioned above, it is the orientation dependence of the electric quadrupolar interaction that permits the study of molecular orientational order, structure and dynamics of lipid membranes by ${ }^{2} \mathrm{H}$ NMR.

On one hand, the use of chain-perdeuterated lipids, deuterated either on one or the two acyl chains, allows the simultaneous investigation of the structure and dynamics of the plateau and the tail regions of the lipid chains. Figure 3 shows an example of the use of deuterium NMR to investigate the effect of two anticancer drugs derived from chloroethylurea (CEU) on the orientational order of lipid acyl chains (20). More specifically, the original and dePaked (deconvolved) ${ }^{2} \mathrm{H}$ NMR spectra obtained at $30^{\circ} \mathrm{C}$ are shown in Figure 3 for pure DMPC deuterated on the sn-2 acyl chain (DMPC- $d_{27}$ ) (Figure 3A) and for DMPC- $d_{27}$ in the presence of 4-sec-butyl CEU and 4-n-butyl CEU (Figures 
$3 \mathrm{~B}$ and $3 \mathrm{C}$, respectively) at a DMPC/CEU molar ratio of 5:1. Both these CEU derivatives contain $R$ substituents with 4 carbon atoms but that differ by their degree of ramification. The use of the dePaking technique (21) allows the possibility to convert the spectrum into one that has the characteristics of a $90^{\circ}$ oriented sample, leading to a better resolution. The results presented in Figure 3 indicate that the order for the first deuterons of the acyl chain is high and decreases rapidly with increasing distance from the carbonyl group $(17,18)$. The results also indicate that both CEU derivatives increase the order of the deuterons located near the interfacial region of the bilayer (20).

${ }^{2} \mathrm{H}$ NMR of the phosphatidylcholine head group has been widely used to examine electrostatic interactions between charged species and a membrane surface $(22,23)$. In such cases, counterdirectional changes in the magnitudes of the $\alpha$ and $\beta$ deuteron quadrupolar splittings have been observed in response to changes in membrane surface charge density. In this respect, phosphatidylcholine is said to behave like a "molecular voltmeter".

\section{${ }^{13} \mathrm{C}$ NMR of Membrane Lipids}

${ }^{13} \mathrm{C}$ NMR spectroscopy is a well suited technique to study lipid bilayers since it allows the simultaneous investigation of different regions of the lipid molecules, i.e. the polar head group, the glycerol backbone and the acyl chains (24). In addition, significant resolution improvement in ${ }^{13} \mathrm{C}$ spectra of lipid bilayers can be achieved by the use of both higher magnetic fields and the magic angle spinning (MAS)

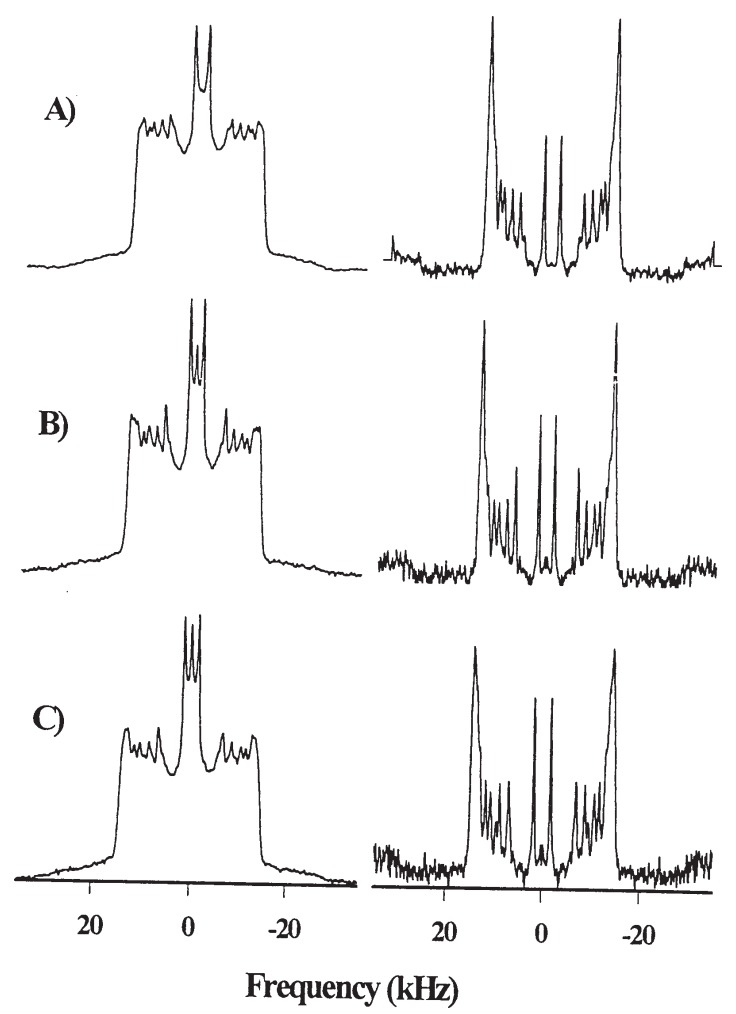

Figure 3. Original (left) and dePaked (right) ${ }^{2} \mathrm{H}-\mathrm{NMR}$ spectra of DMPC- $d_{27}$ in the absence $(A)$ and in the presence of 4-sec-butyl CEU (B) and 4-nbutyl CEU $(\mathrm{C})$ at $30^{\circ} \mathrm{C}$ for a DMPC/CEU molar ratio of $5: 1$ (reproduced from reference 20 , with permission).

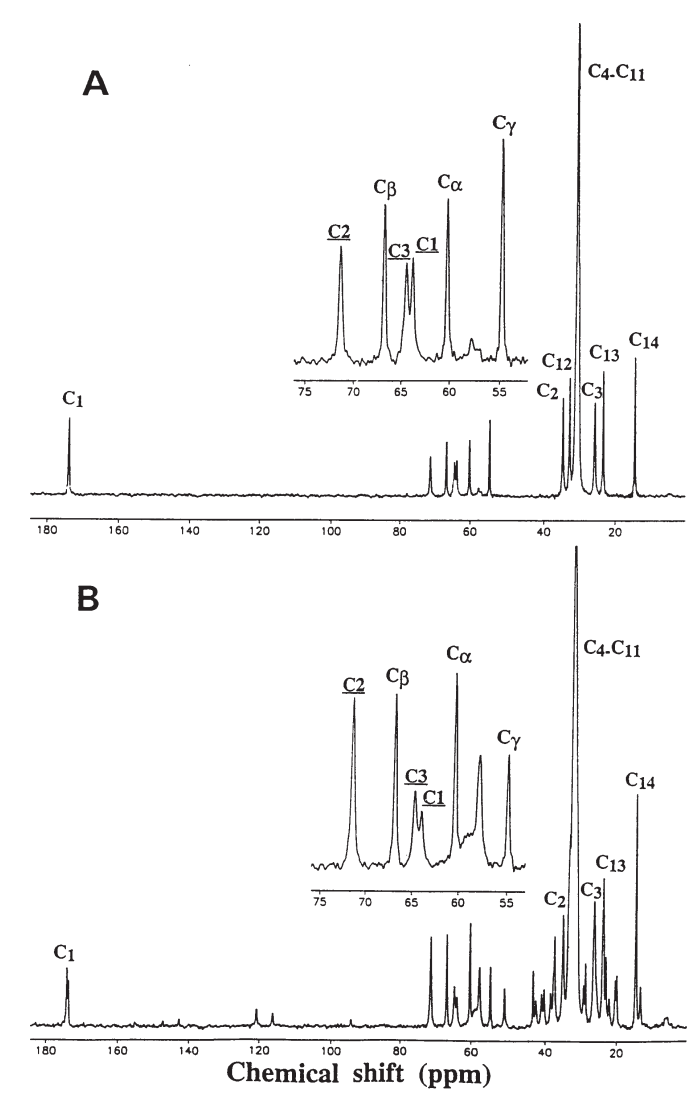

Figure 4. Proton-decoupled ${ }^{13} \mathrm{C}$ NMR spectra of (A) pure DMPC and (B) DMPC-cholesterol (70-30 mol \%) multilamellar dispersions. The spectra were recorded at a temperature of $30^{\circ} \mathrm{C}$ and with a spinning speed of 2 $\mathrm{kHz}$. The insets represent the expansion of the spectral region between 52 and $75 \mathrm{ppm}$. The choline headgroup carbons are indicated by greek letters, those of the glycerol backbone are underlined and the others belong to the acyl chains (reproduced from reference 26 , with permission).

technique, which yields very highly resolved spectra (25).

Figure 4 presents the ${ }^{13} \mathrm{C}$ MAS NMR spectra of pure DMPC multilamellar dispersions and DMPC-cholesterol mixture $(70-30 \mathrm{~mol} \%)$, in excess water, at $30^{\circ} \mathrm{C}$, where the two samples are in the liquid-crystalline lamellar phase (26). As can be seen from this figure, each sample gives a well resolved ${ }^{13} \mathrm{C}$ NMR spectrum in which there are four main spectral regions: the polar head group, the carbonyl groups, the glycerol backbone and the aliphatic acyl chains of the DMPC molecule. Some more resonances, belonging to the cholesterol molecule, can also be observed in the spectrum presented in Figure 4B.

\section{NMR of Membrane Peptides and Proteins}

\section{High Resolution NMR of Peptides and Proteins in} Micelles

The structure of several membrane proteins has been investigated by multidimensional NMR experiments $(7,8)$. These experiments require the solubilization of the proteins with high concentrations of micelle forming lipids in order to obtain a very homogeneous population of small micelles containing a single polypeptide. Proteins in micelles reorient relatively slowly, although rapidly enough to be suitable 

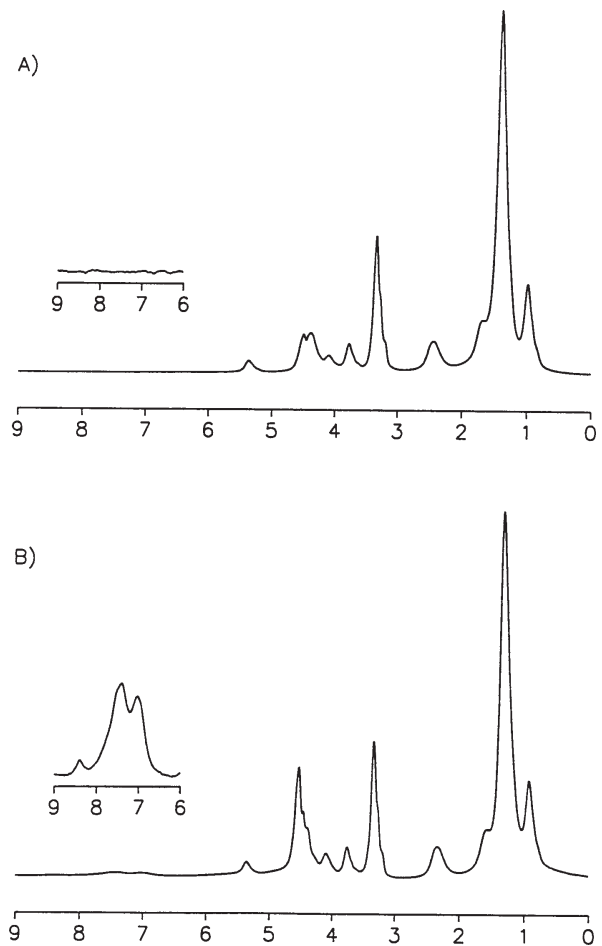

Chemical shift (ppm)

Figure 5. MAS solid-state ${ }^{1} \mathrm{H}$ spectra at $60^{\circ} \mathrm{C}$ of $\mathrm{A}$ ) pure DMPC and $\mathrm{B}$ ) DMPC/gramicidin A system initially prepared from trifluoroethanol. The spinning speed was set to $13.0000 .002 \mathrm{kHz}$ (reproduced from reference 28 , with permission).

for most heteronuclear multidimensional solution NMR experiments in high-field spectrometers (8).

The steps involved in the determination of protein structures in micelles are the same as those used for globular proteins in aqueous solutions and include the resolution and assignment of backbone and side-chain resonances based on through-bond and through-space interactions observed in multidimensional NMR spectra. The structure of several membrane peptides and proteins has been investigated using this approach, including magainin, the major coat protein of filamentous bacteriophages, peptides with sequences that correspond to the transmembrane domain of glycophorin A and peptide sequences from bacteriorhodopsin and phospholamban (for recent reviews, see references 7,8 ).

\section{High-Resolution MAS Proton Spectra of Membrane Peptides}

High-resolution ${ }^{1} \mathrm{H}$ nuclear magnetic resonance (NMR) spectroscopy is a powerful method for protein structure determination in solution (1). However, this method has not been extensively applied to membrane protein systems since the strong homogeneous dipole-dipole broadening between neighboring hydrogen nuclei, which is averaged to zero by rapid isotropic reorientation of molecules in solution, is not completely averaged away in anisotropic non-spinning membrane systems and leads to spectral linewidths of 5 to $25 \mathrm{kHz}$ (10 to $50 \mathrm{ppm}$ depending on the magnetic field strength) (27). However, the use of magic angle spinning rates of about 3 to $4 \mathrm{kHz}$ are sufficient to obtain well resolved ${ }^{1} \mathrm{H}$ spectra from multilamellar dispersions of phospholipids in water, because of the rapid axial diffusion of the phospholipid about its long axis. Although it is possible to obtain well-resolved lipid ${ }^{1} \mathrm{H}$ spectra from multilamellar dispersions, no identifiable peptide signals can be observed at spinning speeds of about 3 to $4 \mathrm{kHz}$ for small peptides, such as gramicidin $\mathrm{A}$, incorporated in phospholipid bilayers. This is due to the presence of additional intermediate time scale motions which broaden the peptide resonances. In this case, it is necessary to spin the sample at a spinning speed faster than that required for phospholipid multilamellar dispersions (27).

One- and two-dimensional ${ }^{1} \mathrm{H}$ NMR spectra of gramicidin A incorporated in a DMPC membrane have been obtained with high-speed MAS $(27,28)$. By rotating the sample at $13 \mathrm{kHz}$, it is possible to observe signals in the ${ }^{1} \mathrm{H}$ spectra between 6.0 and $9.0 \mathrm{ppm}$ attributable to the aromatic protons of the tryptophan residues and the formyl group proton of gramicidin A, as shown in Figure 5. It has also been shown that solvent suppression methods derived from solution NMR, such as presaturation or jump-return, can be used to reduce the water resonance at relatively high water content (29). In addition, regioselective excitation of ${ }^{1} \mathrm{H}$ peptide resonances promotes an efficient

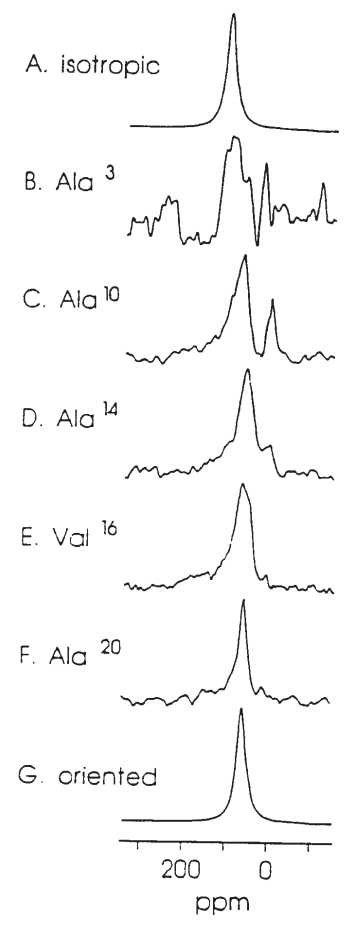

Figure 6. Proton-decoupled ${ }^{15} \mathrm{~N}$ solid-state NMR spectra of PGLa incorporated into oriented POPE/POPG 3/1 phospholipid bilayers. The PGLa concentrations in spectra B-E are $2.3 \mathrm{~mol} \%$ and in spectrum $\mathrm{F}, 1.5$ mol\%. Also shown are simulated ${ }^{15} \mathrm{~N}$ solid-state NMR spectra in the presence of fast motional averaging $(A)$ and of an amide site that is part of an a-helix oriented parallel to the bilayer surface $(G)$ (reproduced from reference 31 , with permission). 


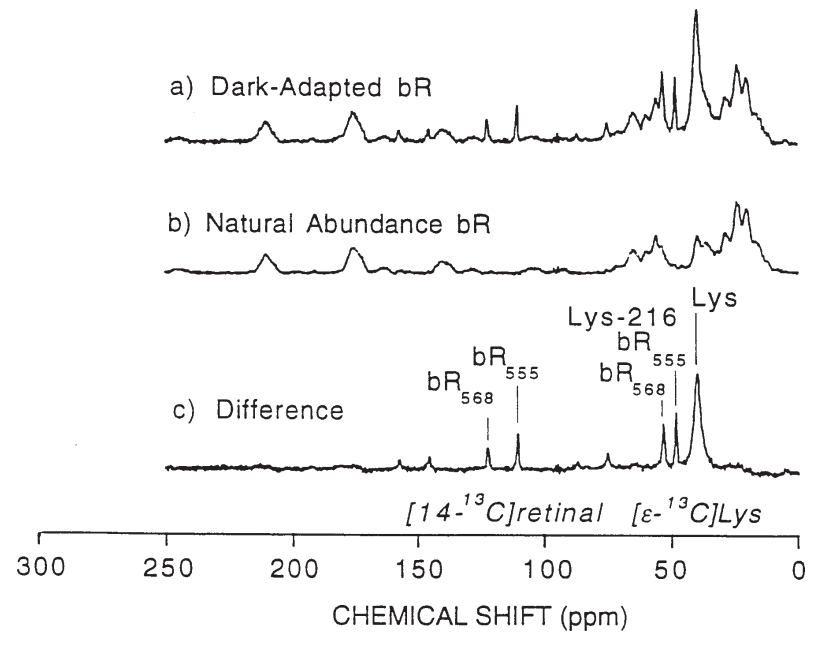

Figure 7. ${ }^{13} \mathrm{C}$ MAS spectra of dark-adapted bR collected at $-80^{\circ} \mathrm{C}$ with a sample spinning speed of $2.8 \mathrm{kHz}$ : (a) $\left[14^{-13} \mathrm{C}\right]$ retinal, $\left[\mathrm{e}^{-13} \mathrm{C}\right] \mathrm{Lys}-\mathrm{bR}$, (b) unlabeled bR, and (c ) the difference spectrum obtained upon subtraction of (b) from (a). The signals at 40,48 and $53 \mathrm{ppm}$ are due to the $\left[\mathrm{e}^{\left.-{ }^{13} \mathrm{C}\right] \text { Lys }}\right.$ label and the signals in the 100 to $130 \mathrm{ppm}$ range arise from the [14$\left.{ }^{13} \mathrm{C}\right]$ retinal marker resonances. Rotational sidebands are observed $35 \mathrm{ppm}$ upfield and downfield of the centerbands (reproduced from reference 33 , with permission).

suppression of lipid resonances, even in cases where these are initially two orders of magnitude more intense (29).

\section{NMR Spectra of Specifically Labeled Membrane Proteins}

Solid-state NMR is a uniquely suited technique to determine the structure of specifically labeled membrane peptides and proteins. Two complementary approaches are most commonly used, the first involving the study of oriented samples in the magnetic field. In this case, the incomplete motional averaging allows the measurement of dipolar couplings, chemical shift anisotropies and electric quadrupolar splittings, from which structural parameters such as torsional angles can be obtained. This technique has been applied to a variety of membrane peptides and proteins, including gramicidin $\mathrm{A}$, bacteriophage proteins and magainin (for recent reviews, see references 7, 8, 30). Figure 6 shows representative solid-state NMR spectra of oriented bilayers containing specifically ${ }^{15} \mathrm{~N}$-labeled PGLa peptide, which is a member of the magainin family of antibiotic peptides found in frog skin and its secretions (31). The spectra of the peptides labeled at the Ala10, Ala14, Val16 and Ala20 positions are characteristic of structured peptides and are indicative of an orientation of the individual $\mathrm{N}-\mathrm{H}$ bond approximately perpendicular to the magnetic field direction.

The second approach uses the magic angle spinning technique to remove these tensor interactions, resulting in spectra which are only characterized by the isotropic chemical shifts and the J-couplings. This technique has been widely used to investigate the structure of the chromophore and of the protein in bacteriorhodopsin and rhodopsin (for recent reviews, see references 6, 30, 32). Figure 7 shows the solid-state ${ }^{13} \mathrm{C}$ NMR MAS spectra of dark-adapted bacteriorhodopsin (bR) (33). The difference spectrum shows signals due only to the $\left[\varepsilon^{-13} \mathrm{C}\right]$ Lys and $\left[14-{ }^{13} \mathrm{C}\right]$ retinal labels. The signals at $110.5 \mathrm{ppm}$ and 122 $\mathrm{ppm}$ are assigned to the $14-{ }^{13} \mathrm{C}$ of retinal of $b_{555}$ and $\mathrm{bR}_{568}$, the two components present in equilibrium in dark adapted bacteriorhodopsin. The remaining signals at 48 and $55 \mathrm{ppm}$ are assigned to the $\varepsilon^{-{ }^{13} \mathrm{C}}$ label in Lys216. These spectra clearly indicate that single labeled sites can be distinguished in magic angle spinning spectra of membrane proteins. The magic angle spinning technique, combined with isotopic labeling, has also been applied to other membrane proteins, including the photosynthetic reaction center and several enzymes and channel peptides (for recent reviews, see references $5,6,30$ ).

Several high-resolution solid-state NMR methods have also been developed in the last ten years to measure weak homonuclear or heteronuclear dipolar couplings in solid samples (for recent reviews, see references 5, 6, 30, 3436). These methods use the magic angle spinning technique and include the rotational resonance and the rfdriven recoupling (RFDR) techniques for the measurement of homonuclear distances and techniques such as REDOR and TEDOR for the measurement of heteronuclear distances. These techniques have been applied to a variety of systems including the membrane proteins rhodopsin and bacteriorhodopsin, gramicidin $\mathrm{A}$, glycophorin $\mathrm{A}$ and $\mathrm{a}$ bacterial chemotaxis membrane receptor $(5,6,30,34-36)$. In addition, several methods have been developed recently for the measurements of torsion angles from magic angle spinning spectra in solids. These methods directly investigate molecular geometry by determining the relative orientation of pairs of nuclear spin interactions (36).

\section{Perspectives}

The experiments described above for the measurements of internuclear distances or torsional angles in membrane peptides and proteins have all been performed with spin pairs, either ${ }^{13} \mathrm{C}-{ }^{13} \mathrm{C}$ or ${ }^{15} \mathrm{~N}-{ }^{13} \mathrm{C}$. However, the synthesis of specifically labeled molecules is difficult and expensive in comparison with biosynthetic methods which yields uniformly ${ }^{13} \mathrm{C} /{ }^{15} \mathrm{~N}$ labeled systems (36). Therefore, the determination of protein structure from completely labeled proteins would be an interesting alternative. However, the major problem associated with a uniformly labeled sample in solid-state NMR is the multiple strong couplings which prevent the observation of weaker couplings and which results in increased linewidths. Recently, a very careful analysis has been made on the impact of linewidths on multidimensional solid-state NMR spectra of uniformly labeled peptides and proteins (37). The main conclusion of this study is that the length of a peptide for which a complete, unique assignment of ${ }^{13} \mathrm{C}$ and ${ }^{15} \mathrm{~N}$ backbone resonances in solid-state NMR spectra is feasible is strongly limited by spectral resolution. For peptides of 20 to 30 amino acid residues, resolutions better than $0.5-1.5$ ppm or 0.5-1.0 ppm, respectively, are required (37). Several avenues have recently been suggested to increase both the spectral resolution and sensitivity (36). These include the use of higher field spectrometers, the development of new labeling strategies to improve the resolution and the use of higher dimensional experiments. These 
developments should increase the number of membrane proteins for which the structure can be investigated by solidstate NMR spectroscopy.

\section{References}

1. Wüthrich, K. 1986. NMR of Proteins and Nucleic Acids. Wiley, New Work

2. Evans, J.S. 1995. Biomolecular NMR. Oxford University Press, Oxford

3. Griffin, R.G. 1981. Solid state nuclear magnetic resonance of lipid bilayers. Methods Enzymol. 72: 108-174.

4. Bloom, M. and Bayerl, T.M. 1995. Membranes studied using neutron scattering and NMR. Can. J. Phys. 73: 687-696.

5. Watts, A., Ulrich, A.S. and Middleton, D.A. 1995. Membrane protein structure: the contribution and potential of novel solid state NMR approaches. Mol. Membr. Biol. 12: 233-246.

6. Smith, S.O., Aschheim, K. and Groesbeek, M. 1996. Magic angle spinning NMR spectroscopy of membrane proteins. Q. Rev. Biophys. 29: 395-449.

7. Opella, S.J. 1997. NMR and membrane proteins. Nature Struct. Biol 4: 845-848.

8. Opella, S.J. and Marassi, F.M. 1996. Membrane proteins. In Encyclopedia of Nuclear Magnetic Resonance. D.M. Grant and R.K. Harris, eds. John Wiley, Toronto, Canada. p. 2994-3003.

9. Sanders, C.R. and Schwonek, J.P. 1992. Characterization of magnetically orientable bilayers in mixtures of dihexanoylophosphatidylcholine and dimyristoylphosphatidyl-choline by solid-state NMR. Biochem. 31: 8898-8909.

10. Sanders, C.R. and Prosser, R.S. 1998. Bicelles: a model membrane system for all seasons? Structure. 6: 1227-1234

11. Yeagle, P.L. 1996. Membranes: Phosphorus-31 NMR. In: Encyclopedia of Nuclear Magnetic Resonance. D.M. Grant and R.K. Harris, eds. John Wiley, Toronto, Canada. p. 3015-3022.

12. Smith, I.C.P. and Ekiel, I.H. 1984. Phosphorus-31 NMR of phospholipids in membranes. In: Phosphorus-31 NMR: Principles and applications. D. Gorenstein, ed. Academic Press Inc. London, England. p. 447-475.

13. Seelig, J. 1978. ${ }^{31} \mathrm{P}$ nuclear magnetic resonance and the head group structure of phospholipids in membranes. Biochim. Biophys. Acta. 515: 105-140.

14. Picard, F., Pézolet, M., Bougis, P.E. and Auger, M. 1996. Model of interaction between a cardiotoxin and dimyristoylphosphatidic acid bilayers determined by solid-state ${ }^{31} \mathrm{P}$ NMR spectroscopy. Biophys. J. 70: 1737-1744.

15. Fenske, D.B. and Jarrell, H.C. 1991. Phosphorus-31 two-dimensiona solid-state NMR: Application to model membrane and biological systems. Biophys. J. 59: 55-69.

16. Picard, F., Paquet, M.-J., Dufourc, E.J. and Auger, M. 1998 Measurement of the lateral diffusion of dipalmitoylphosphatidylcholine adsorbed on silica beads in the absence and presence of melittin: A ${ }^{31} \mathrm{P} 2 \mathrm{D}$ exchange solid-state NMR study. Biophys. J. 74: 857-868.

17. Davis, J.H. 1983. The description of membrane lipid conformation order and dynamics by ${ }^{2} \mathrm{H}-\mathrm{NMR}$. Biochim. Biophys. Acta. 737: 117171.

18. Seelig, J. 1977. Deuterium magnetic resonance: theory and applications to lipid membranes. Q. Rev. Biophys. 10: 353-418.

19. Davis, J.H. 1996. Membranes: Deuterium NMR. In: Encyclopedia of Nuclear Magnetic Resonance. D.M. Grant and R.K. Harris, eds. John Wiley, Toronto, Canada. p. 3008-3015.

20. Saint-Laurent, A., Boudreau, N., C.-Gaudreault, R., Poyet, P. and Auger, M. 1998. Interaction between lipid bilayers and a new class of antineoplastic agents derived from arylchloroethylurea: $\mathrm{A}^{2} \mathrm{H}$ solidstate NMR study. Biochem. Cell Biol. 76: 465-471.

21. Bloom, M., Davis, J.H. and MacKay, A.L. 1981. Direct determination of the oriented sample NMR spectrum from the powder spectrum for systems with local axial symmetry. Chem. Phys. Lett. 80: 198-202.

22. Seelig, J., Macdonald, P.M. and Scherer, P.G. 1987. Phospholipid head groups as sensors of electric charge in membranes. Biochem. 26: 7535-7541.

23. Macdonald, P.M. 1997. Deuterium NMR and the topography of surface electrostatic charge. Acc. Chem. Res. 30: 196-203.

24. Separovic, F. and Cornell, B.A.. 1996. Membranes: Carbone-13 NMR In: Encyclopedia of Nuclear Magnetic Resonance. D.M. Grant and R.K. Harris, eds. John Wiley, Toronto, Canada. p. 3003-3008.

25. Forbes, J., Bowers, J., Shan, X. Moran, L and Oldfield, E. 1988 Some new developments in solid-state nuclear magnetic resonance spectroscopic studies of lipids and biological membranes, including the effects of cholesterol in model and natural systems. J. Chem.
Soc., Faraday Trans. 1. 84: 3821-3849.

26. Le Guernevé, C. and Auger, M. 1995. New approach to study fas and slow motions in lipid bilayers: Application to DMPC-cholesterol interactions. Biophys. J. 68: 1952-1959.

27. Davis, J.H., Auger, M. and Hodges, R.S. 1995. High resolution ${ }^{1} \mathrm{H}$ NMR of a transmembrane peptide. Biophys. J. 69: 1917-1932.

28. Bouchard, M., Davis, J.H. and Auger, M. 1995. High-speed MAS solidstate ${ }^{1} \mathrm{H}$ NMR study of the conformation of gramicidin A in lipid bilayers. Biophys. J. 69: 1933-1938.

29. Le Guernevé, C. and Seigneuret, M. 1996. High-resolution monoand multidimensional magic angle spinning ${ }^{1} \mathrm{H}$ nuclear magnetic resonance of membrane peptides in nondeuterated lipid membranes and $\mathrm{H}_{2} \mathrm{O}$. Biophys. J. 71: 2633-2644.

30. Davis, J.H. and Auger, M. 1999. Static and magic angle spinning NMR of membrane peptides and proteins. Prog. NMR Spectrosc. 35: 1-84.

31. Bechinger, B., Zasloff, M. and Opella, S.J. 1998. Structure and dynamics of the antibiotic peptide PGLa in membranes by solution and solid-state nuclear magnetic resonance spectroscopy. Biophys. J. 74: 981-987.

32. Engelhard, M. and Bechinger, B. 1996. Application of NMRspectroscopy to retinal proteins. Israel J. Chem. 35: 273-288.

33. Farrar, M.R., Lakshmi, K.V., Smith, S.O., Brown, R.S., Raap, J., Lugtenburg, J., Griffin, R.G. and Herzfeld, J. 1993. Solid state NMR study of $\left[\mathrm{e}^{-13} \mathrm{C}\right]$ Lys-bacteriorhodopsin schiff base photoisomerization. Biophys. J. 65: 310-315.

34. Auger, M. 1995. Solid state NMR study of protein structure: Methods based on the measurement of internuclear distances. J. Chim. Phys. 92: $1751-1760$

35. Griffiths, J.M. and Griffin, R.G. 1993. Nuclear magnetic resonance methods for measuring dipolar couplings in rotating solids. Anal. Chim. Acta. 283: 1081-1101.

36. Griffin, R.G. 1998. Dipolar recoupling in MAS spectra of biological solids. Nature Struct. Biology. 5: 508-512.

37. Tycko, R. 1996. Prospects for resonance assignments in multidimensional solid-state NMR spectra of uniformly labeled proteins. J. Biomol. NMR. 8: 239-251. 


\section{Further Reading}

Caister Academic Press is a leading academic publisher of advanced texts in microbiology, molecular biology and medical research. Full details of all our publications at caister.com

- MALDI-TOF Mass Spectrometry in Microbiology Edited by: M Kostrzewa, S Schubert (2016) www.caister.com/malditof

- Aspergillus and Penicillium in the Post-genomic Era Edited by: RP Vries, IB Gelber, MR Andersen (2016) www.caister.com/aspergillus2

- The Bacteriocins: Current Knowledge and Future Prospects Edited by: RL Dorit, SM Roy, MA Riley (2016)

www.caister.com/bacteriocins

- Omics in Plant Disease Resistance Edited by: V Bhadauria (2016) www.caister.com/opd

- Acidophiles: Life in Extremely Acidic Environments Edited by: R Quatrini, DB Johnson (2016) www.caister.com/acidophiles

- Climate Change and Microbial Ecology: Current Research and Future Trend

Edited by: J Marxsen (2016)

www.caister.com/climate

- Biofilms in Bioremediation: Current Research and Emerging Technologies

Edited by: G Lear (2016)

www.caister.com/biorem

- Microalgae: Current Research and Applications Edited by: MN Tsaloglou (2016) www.caister.com/microalgae

- Gas Plasma Sterilization in Microbiology: Theory, Applications, Pitfalls and New Perspectives Edited by: H Shintani, A Sakudo (2016) www.caister.com/gasplasma

- Virus Evolution: Current Research and Future Directions Edited by: SC Weaver, M Denison, M Roossinck, et al. (2016) www.caister.com/virusevol

- Arboviruses: Molecular Biology, Evolution and Control Edited by: N Vasilakis, DJ Gubler (2016) www.caister.com/arbo

- Shigella: Molecular and Cellular Biology Edited by: WD Picking, WL Picking (2016) www.caister.com/shigella

-Aquatic Biofilms: Ecology, Water Quality and Wastewater Treatment

Edited by: AM Romaní, H Guasch, MD Balaguer (2016)

www.caister.com/aquaticbiofilms

- Alphaviruses: Current Biology

Edited by: S Mahalingam, L Herrero, B Herring (2016)

www.caister.com/alpha

- Thermophilic Microorganisms

Edited by: F Li (2015)

www.caister.com/thermophile
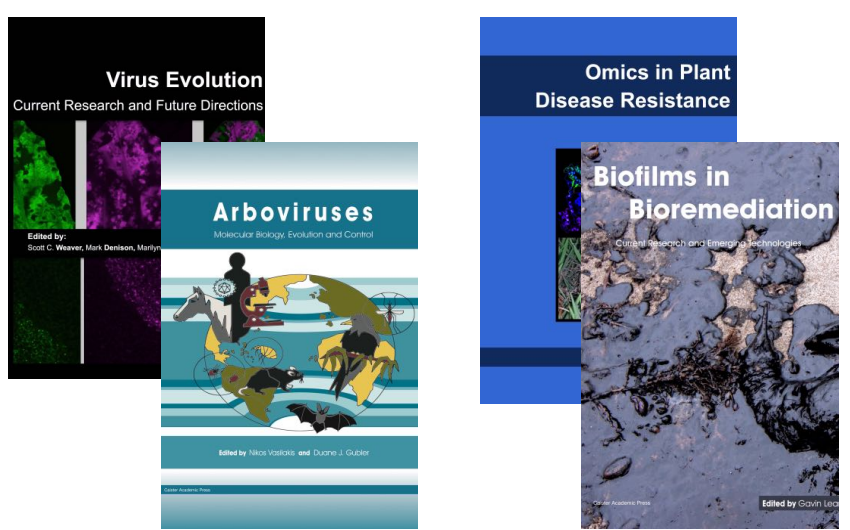
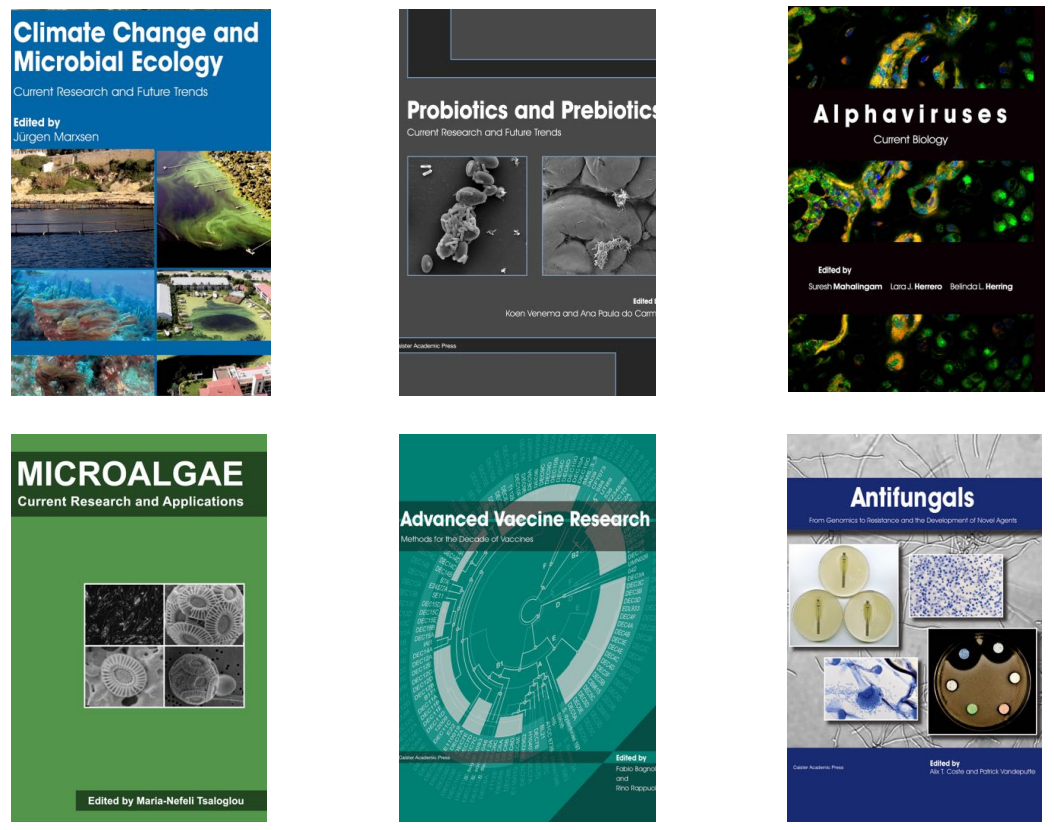

- Flow Cytometry in Microbiology: Technology and Applications Edited by: MG Wilkinson (2015) www.caister.com/flow

- Probiotics and Prebiotics: Current Research and Future Trends Edited by: K Venema, AP Carmo (2015) www.caister.com/probiotics

- Epigenetics: Current Research and Emerging Trends Edited by: BP Chadwick (2015) www.caister.com/epigenetics2015

- Corynebacterium glutamicum: From Systems Biology to Biotechnological Applications

Edited by: A Burkovski (2015)

www.caister.com/cory2

- Advanced Vaccine Research Methods for the Decade of Vaccines

Edited by: F Bagnoli, R Rappuoli (2015)

www.caister.com/vaccines

- Antifungals: From Genomics to Resistance and the Development of Novel Agents

Edited by: AT Coste, P Vandeputte (2015)

www.caister.com/antifungals

- Bacteria-Plant Interactions: Advanced Research and Future Trends Edited by: J Murillo, BA Vinatzer, RW Jackson, et al. (2015) www.caister.com/bacteria-plant

\section{- Aeromonas}

Edited by: J Graf (2015)

www.caister.com/aeromonas

- Antibiotics: Current Innovations and Future Trends

Edited by: S Sánchez, AL Demain (2015)

www.caister.com/antibiotics

- Leishmania: Current Biology and Contro Edited by: S Adak, R Datta (2015) www.caister.com/leish2

- Acanthamoeba: Biology and Pathogenesis (2nd edition) Author: NA Khan (2015)

www.caister.com/acanthamoeba2

- Microarrays: Current Technology, Innovations and Applications Edited by: Z He (2014)

www.caister.com/microarrays2

- Metagenomics of the Microbial Nitrogen Cycle: Theory, Methods and Applications

Edited by: D Marco (2014)

www.caister.com/n2 